Available Online : https://proceeding.researchsynergypress.com/index.php/cset/index

RSF Conference Series: Engineering and Technology

ISSN 2809-6843 (Online) | 2809-6878 (Print)

Volume 1 Number 1 (2021): 433-452

\title{
Groundwater Vulnerability towards Pollution in Area Around the Piyungan Landfill, Bantul Regency, D. I. Yogyakarta
}

\section{RR. Dina Asrifah'1, Ika Wahyuning Widiarti'2, Praditya Anggi Widhiananto ${ }^{3}$, Lailiyatun Ni'ma $^{4}$, Dzulfiqar Izzatur Rahman ${ }^{5}$, Aliendina Jwalita', Hafidz Romizah ${ }^{7}$}

\author{
1,2,3,4,5,6,7 Environmental Engineering Department, UPN “Veteran" Yogyakarta, Indonesia
}

\begin{abstract}
The Piyungan landfill is located in Bantul Regency, Daerah Istimewa Yogyakarta, still uses an open dumping system. The open dumping system produced more quantity of leachate from other systems. Leachate spreads to the ground and seeps into the ground to the groundwater surface. These conditions have an impact on the environment. This study aims to assess the groundwater vulnerability to leachate contamination in the area around the Piyungan landfill. The research method used is survey and mapping, and data analysis is carried out using the Le Grand method. Geographic Information System (GIS) is also used to visualize data into maps. The Le Grand method considers as many as 5 physical environmental parameters, including the groundwater depth, absorptionaboveground,aquiferpermeability,groundwaterslope, and horizontaldistanceofwells with pollutant sources. Next, scoring is carried out for each of these parameters, and then a groundwater vulnerability map is made using the overlay method. The results of the study were three classes of the potential vulnerability of groundwater pollutions. That were large pollution potential (may or may be polluted), medium pollution potential (maybe polluted but slightly), and small pollution potential (very difficult to pollute).
\end{abstract}

Keywords: Groundwater Pollution, Leachate, Le Grand, Vulnerability

\section{INTRODUCTION}

This is an open accessarticleunder theCC-BY-NClicense

The increasingly diverse human needs ultimately increase the amount of waste and waste generated, both from domestic activities, industry, agriculture, and other activities. Most people only collect and pile waste to the landfill without any processing first so that the current landfill can pose a pollution threat. This condition causes landfills to turn into open dumping. The main problem was the potential to arise from the existence of the landfill. There is the release of leachate from rainwater percolation through garbage, thereby making water resources contaminated by pollutants. Leachate can move to surface water, soil, and even into groundwater. High levels of contaminants in groundwater can cause the quality of the groundwater to decline.

Leachate is water produced from a mixture of the percolation process by rainwater. Treatment of leachate is often complicated by its occurrence which varies and depends on the climate, surface conditions, type of waste, and location (Bhalla et. al., 2012). Effective leachate treatment technology is very important to be applied in processing (Guanyi et. al., 2021). Leachate can worsen groundwater quality, mainly has located around a landfill, due to the content in leachate that can cause pollutants such as minerals, organic compounds, inorganic minerals, heavy metals, bacteria, and viruses to contaminate groundwater. Heavy metals contained in landfill leachate can cause acute toxicity and carcinogenic effects on living things, especially humans (Gajski at. al., 2012). The condition becomes worse if it turns out that the geophysical conditions in the area around the landfill have a high level of vulnerability. Groundwater vulnerability will increase along with the position of the landfill, closed in the groundwater well to the landfill location, the groundwater quality will become more vulnerable. (Gamar et.al., 2018). Groundwater is a substantial part of water resources to support human survival. The important thing behind this research is that clean water and sanitation are important factors to support sustainable development following the goals set out in the Sustainable Development Goals (SDGs). Therefore, this research is very important to be carried out and known by the community to provide an understanding of the importance of maintaining the 
RSF Conference Series: Engineering and Technology

Vol. 1 (1), 443-452

Groundwater Vulnerability towards Pollution in Area Around the Piyungan Landfill, Bantul Regency, D. I. Yogyakarta

RR. Dina Asrifah, Ika Wahyuning Widiarti, Praditya Anggi Widhiananto, Lailiyatun Ni'ma, Dzulfiqar Izzatur Rahman, Aliendina Jwalita, Hafidz Romizah

quality of water sources. The purpose of this study was to determine the level of vulnerability of groundwater to pollution around the Piyungan landfill, as well as to determine the direction of the next landfill management.

\section{LITERATURE REVIEW}

The research location is in the area around the Piyungan Landfill, Bantul Regency, D. I. Yogyakarta. Initially, this landfill has designed using a sanitary landfill system, but as time goes by because increasing garbages were comingin.

The average municipal solid waste generated in the province of D.I. Yogyakarta reaches 470 tons/day, where organic waste dominates with a percentage of up to $77 \%$. (Sudibyo et. al., 2017). The Piyungan landfill accommodates garbage from several surrounding districts, which until now has been piling up more and more garbage. The right step in reducing the amount of solid waste should be by increasing the role of the Integrated Waste Management Site (TPST) in their respective regions in reducing waste before it is transported to the Piyungan landfill.

The Piyunganlandfill has been operating since 1996 until now still uses an open dumping system so that there is still the possibility to produce leachate. Leachate is water produced from a mixture of the percolation process by rainwater, a solution of solid waste biodegradation, and water from the waste itself. Leachate generally contains pollutantmaterialsthatcan reducegroundwaterquality(Chunyinget.al., 2021).

To protect water resources, a ground water vulnerability assessment is needed that aims to determine areas where groundwater may be more vulnerable to pollution (Wanzhou et. al., 2022). According to the US EPA, groundwater vulnerability is the level of ease with which contaminants can contaminate aquifer systems (ACSAD \& BGR, 2003). Groundwater vulnerability assessment is needed to determine the possibility of groundwater contamination.

One of the methods of assessing groundwater vulnerability to evaluate potential contamination is the Le Grand method (1964). Le Grand method takes into account 5 physical parameters, including the depth of the groundwater table, the horizontal distance from the pollutant source, absorption above the soil surface, aquifer permeability, and groundwater slope (Singhal \& Gupta,2010). This method is devoted to one type of pollutantsource.

Assessmentforthepreventionofgroundwaterpollutionisamoreeffectivewaythanhandlingit(Machdar et.al., 2018). Research on potential groundwater vulnerability has also been studied intensively through several approaches in previous years. Previous research conducted by Nnadozie et. al. (2019) evaluates the vulnerability of groundwater to pollution using several approaches, one of which is the Le Grand method, in the region of Southeastern Nigeria. In carrying out the assessment, they integrate the data of geology, geotechnical and geophysical.

\section{RESEARCH METHODOLOGI}

\section{A. Data Collection}

The data required consists of data on each vulnerability parameter obtained based on direct observations in the field and from secondary data. The data taken directly in the field are groundwater depth data and crosscheck soil texture, while data on groundwater level slope and horizontal distance from pollutant sources are obtained from calculation analysis using ArcGIS software. As for the aquifer permeability parameters obtained from the drill log data of the Department of Public Works, Housing, and Energy and Mineral Resources of the D.I. Yogyakarta in 2016. 
RSF Conference Series: Engineering and Technology

Vol. 1 (1), 443-452

Groundwater Vulnerability towards Pollution in Area Around the Piyungan Landfill, Bantul Regency, D. I. Yogyakarta

RR. Dina Asrifah, Ika Wahyuning Widiarti, Praditya Anggi Widhiananto, Lailiyatun Ni'ma, Dzulfiqar Izzatur Rahman, Aliendina Jwalita, Hafidz Romizah

\section{B. Data Analysis}

The level of vulnerability of groundwater from pollutant contamination is analyzed from 5 aspects according to Le Grand. Aspects to be considered are as follows :

1. Groundwater Depth

Groundwater level is certainly very influential on the size of the pollutant contamination. The shallower the depth of the groundwater table, the more easily it will be contaminated with pollutant flows. The groundwater table depth score can be seen in the following figure :

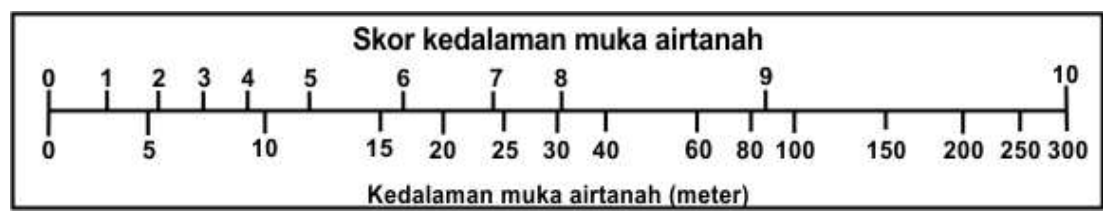

Figure 1. Diagram of Groundwater table depth

2. Absorption Above Ground

Absorption above ground is obtained from reading the soil map and cross-checking the soil texture at the research site. Le Grand assessed that the coarser the soil constituent material, the greater the potential forpollution.Theabsorptionscoreabovethegroundwatertablepresentedinthefollowing image:

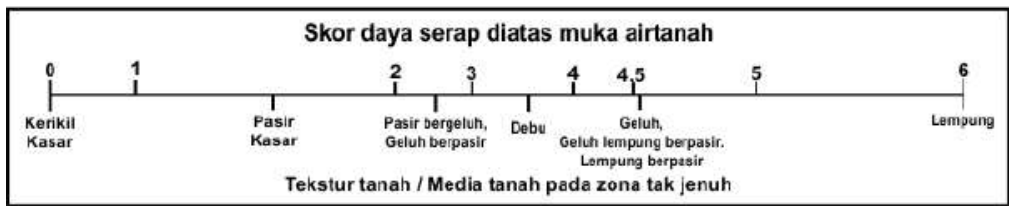

Figure 2. Diagram of water absorption score above ground level

3. Aquifer Permeability

Determined based on the material that makes up the aquifer. This parameter is related to the process of contaminants reaching the groundwater surface, if the aquifer permeability is high, it can make it easier for contaminants to seep into groundwater. The permeability score can be seen in the following figure:

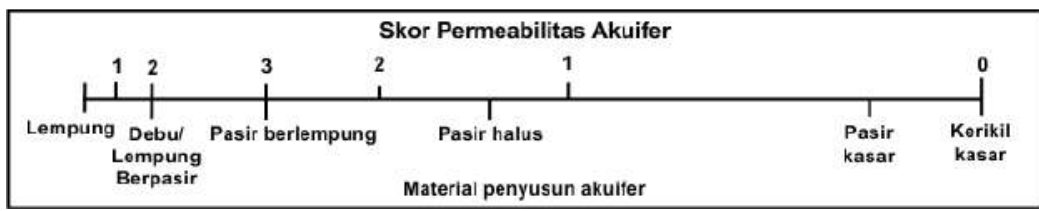

Figure 3. Diagram of aquifer permeability score

4. Groundwater Slope

Affects the speed of contamination of contaminants to groundwater. The higher the level of groundwater slope with a pollutant source, the movement of contaminants to groundwater will also be faster. The slope score can be seen in the following figure: 


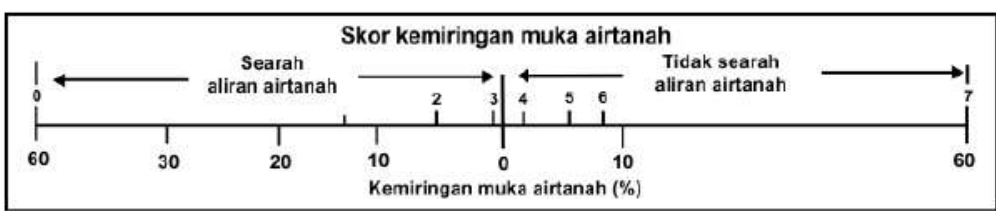

Figure 4. Diagram of groundwater slope score

5. Horizontal Distance of Wells with Pollutant Sources

The closer the distance to the pollutant source, the smaller the score, so the potential for vulnerability to pollution is greater. The horizontal distance score of the well with the pollutant source can be seen in the following figure:

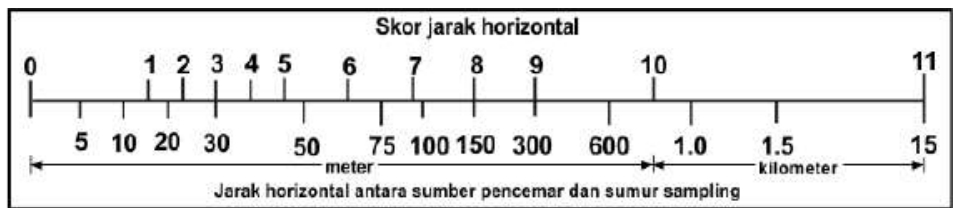

Figure 5. Diagram of the horizontal distance of the well with the pollutant source

The value on each graph is read by looking at the numbers at the top of the line and adjusted for the data at the bottom of the line. Data analysis is calculating the score of each parameter. Furthermore, the scoring map of 5 (five) parameters of potential vulnerability to groundwater pollution is superimposed using the overlay method in Geographic Information System (GIS). The map overlay has done using ArcGIS software. The final result of the map overlay is a Map of Groundwater Vulnerability to Pollution. While the results of the total scoring of each parameter will produce classes of potential pollutions, as in the following table.

Table 1. Pollution Potential Scoring

\begin{tabular}{|c|c|c|}
\hline No. & Total Score & Pollution Potential Class \\
\hline $\mathbf{1 .}$ & $0-4$ & Very large (very likely polluted) \\
\hline $\mathbf{2}$ & $\mathbf{5 - 8}$ & Large (could or might be polluted) \\
\hline $\mathbf{3}$ & $9-12$ & Moderate (maybe polluted but slightly) \\
\hline $\mathbf{4 .}$ & $13-25$ & Small (very difficult to pollute) \\
\hline $\mathbf{5 .}$ & $26-35$ & Very small (almost impossible to pollute) \\
\hline
\end{tabular}

\section{FINDING AND DISCUSSION}

A. Parameters of Groundwater Vulnerability Analysis

1. The Depth of The Groundwater Table

Based on the results of the measurement study of 36 wells in the field, the research area has a groundwater level that varies from 1-10 meters. The dominating groundwater level is at shallow depths (+ 1-5 meters), especially those around the landfill. The shallower depth of the groundwater table will increase the vulnerability to groundwater pollution. The groundwater characteristic in the study area was included in the unconfined aquifer. 


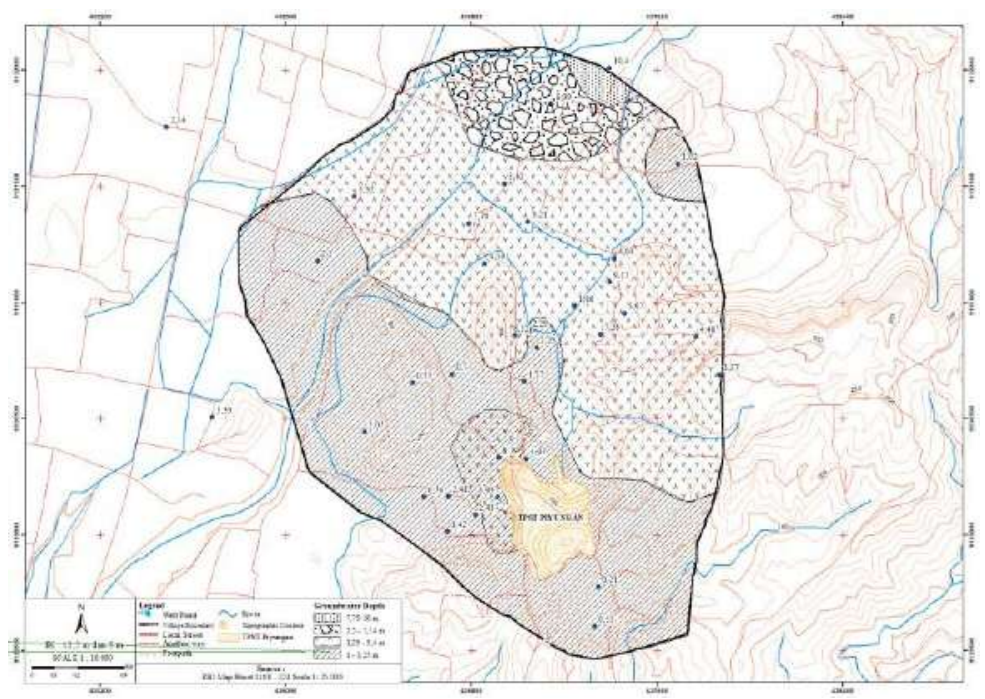

Figure 6. Map of Groundwater Table

\section{Absorption Above The Water Table}

Based on drill log data, the aquifer material in the study area is sand to clay. The soil texture in the study area is Loam sand (Score 2,5), Sandy loam (Score 4,5), Clay loam (Score 3,5), and Silty clay (Score 5). The dominant soil texture was Loamsand and clay loam. The coarser the grain size of the soil constituent material, the greater the potential forgroundwater contamination.

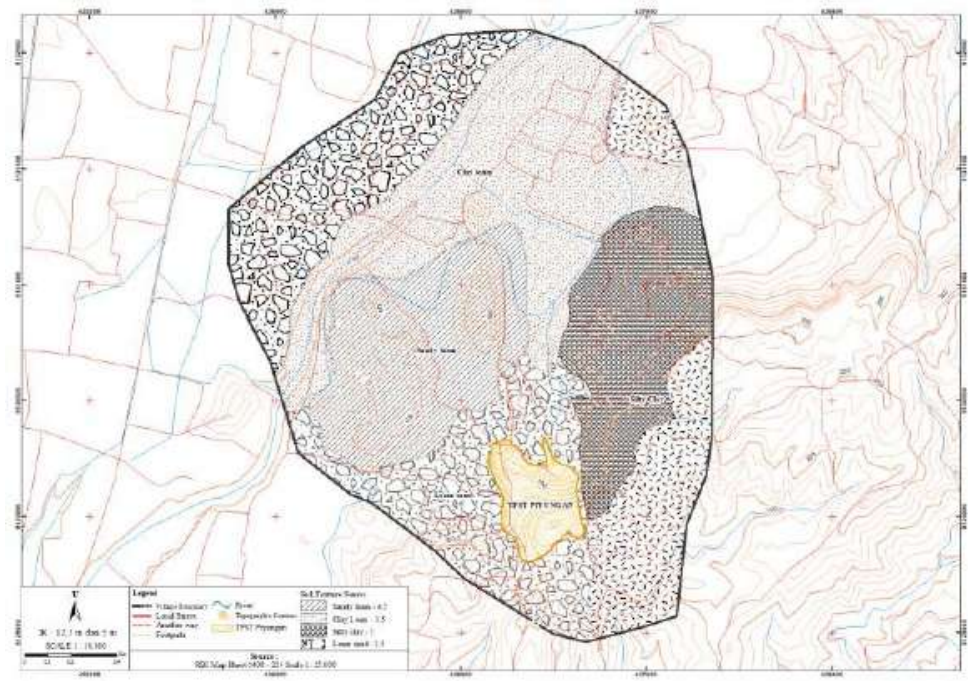

Figure 7. Map of Absorption above the water table

3. Aquifer Permeability

The condition of theaquiferinthestudyarea wascomposed of medium sand material withamixture of clay whichcausesrunofftoinfiltratewell. Thehydraulicconductivityvalue of theaquifer, whichis composed of layers of sand, clay, clay sand, and fine sands were 11,76 m/day (score 1,692). Based on the hydraulic conductivityvalue, theaquiferpermeabilitylevelinthestudyareaisclassified asfast. 
Groundwater Vulnerability towards Pollution in Area Around the Piyungan Landfill, Bantul Regency, D. I. Yogyakarta

RR. Dina Asrifah, Ika Wahyuning Widiarti, Praditya Anggi Widhiananto, Lailiyatun Ni'ma, Dzulfiqar Izzatur Rahman, Aliendina Jwalita, Hafidz Romizah

The faster the aquifer permeability rate, the higher the potential for groundwater pollution susceptibility.

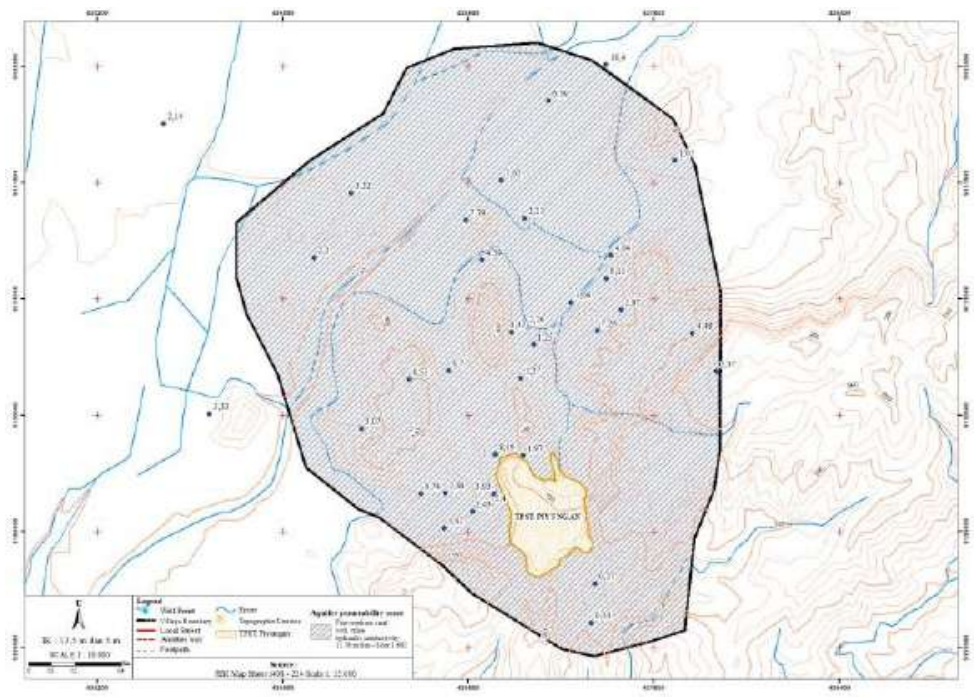

Figure 8. Map of Aquifer Permeability

\section{Groundwater Slope}

The highest slope is $18.84 \%$ and the lowest slope is $0.2 \%$. The slope of groundwater, especially around the landfill, has a slope angle of between $1 \%-8 \%$. The higher the level of groundwater slope, the higher the potential vulnerability of groundwater to pollution. The point of the well near the landfill has a slope in the direction of the wells below it so that it will be easier for leachate to flow into wells close to residential areas.The large slope of the groundwater has a large potential for contamination as well.

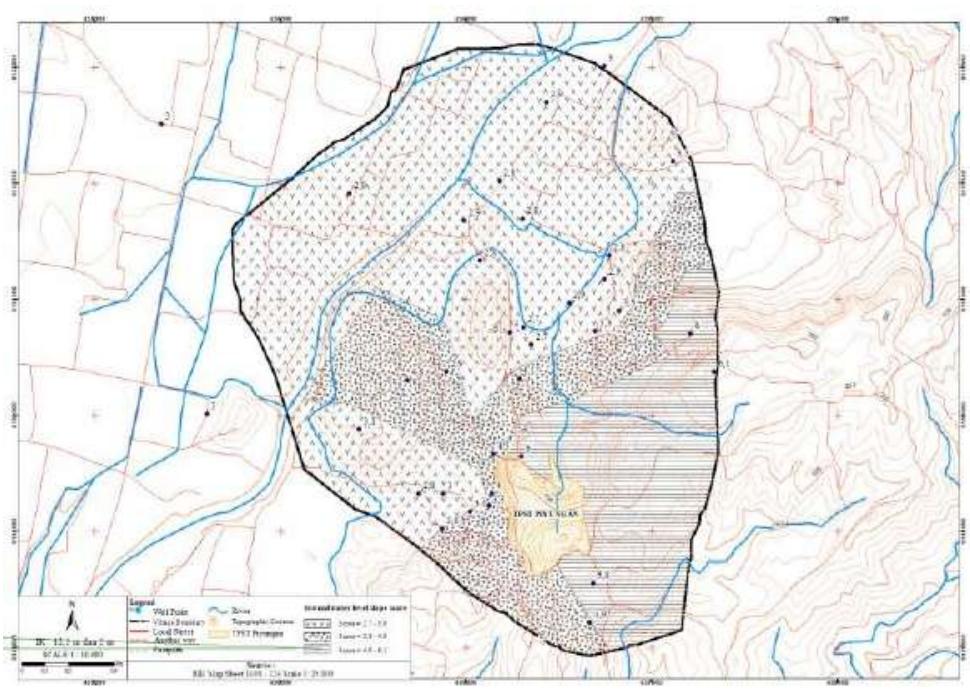

Figure 9. Map of Groundwater Slope 
Groundwater Vulnerability towards Pollution in Area Around the Piyungan Landfill, Bantul Regency, D. I. Yogyakarta

RR. Dina Asrifah, Ika Wahyuning Widiarti, Praditya Anggi Widhiananto, Lailiyatun Ni'ma, Dzulfiqar Izzatur Rahman, Aliendina Jwalita, Hafidz Romizah

\section{The Horizontal Distance of The Well from The Pollutant}

The horizontal distance of the well to the pollutant source at the study site varies greatly $( \pm 300-2000$ meters). Wells located close to the landfill have a higher level of vulnerability to pollution. There are about 10 dug wells which are located quite close to the Piyungan landfill. These wells will certainly have more potential to be contaminated by contaminants, especiallyleachate.

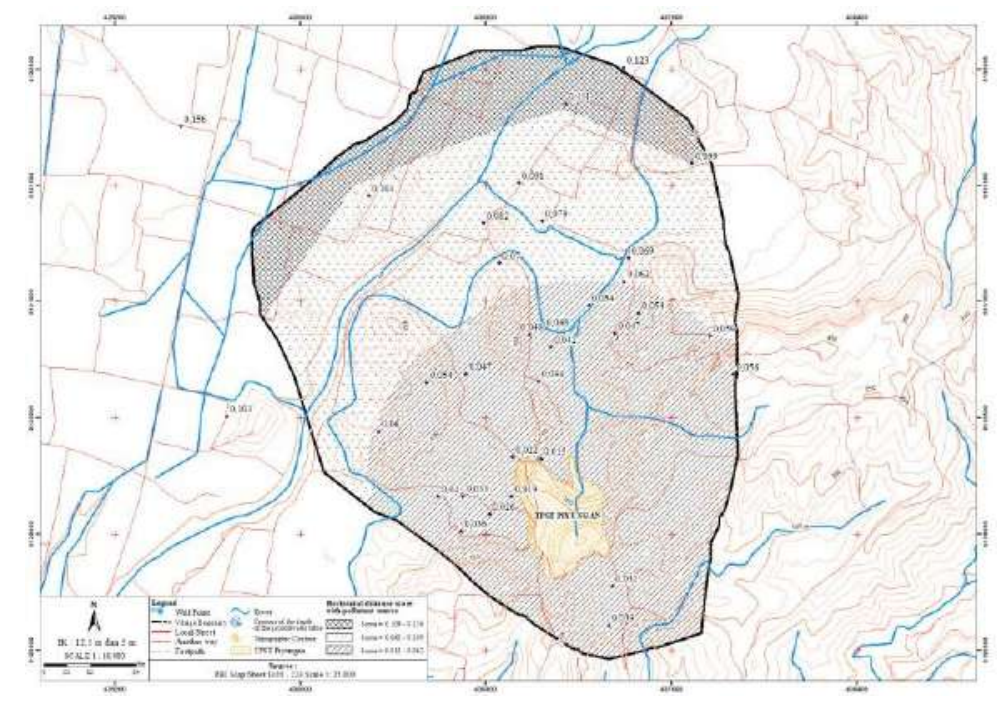

Figure 10. Map of Horizontal Distance to Pollutant Source

B. Groundwater Vulnerability Map Results

The level of groundwater vulnerability to pollution was analyzed based on the Le Grand parameter, then scoring and overlaying the entire map was carried out. The total scoring results are obtained from the sum of all Le Grand parameter scores using the overlay method in ArcGIS software. The results of the scoring calculation show different values. The potential for pollution that occurs in the research area based on the Le Grand method is divided into 4 classes, namely the class of very large pollution potential (Total score 0-4), large pollution potential (Total score 5-8), moderate pollution potential (Total score 912), and the potential for pollution is small (Total Score 13-25). The scoring value is calculated by several factors that have been mentioned. Based on the results of scoring using the Le Grand method and overlaying a map of all parameters, at the research location, there are 3 classes of Pollution Potential, namely Large Pollution Potential, which means that the area can or may experience pollution; Moderate Pollution Potential, which means that it has the potential to be polluted even though it is slightly; Small Pollution Potential, which means it is very difficult to pollute. This condition needs to be taken into account because the research area is dominated by Large and Medium Pollution Potential Classes where it is still possible for pollution to occur. There needs to be a synergy between the management of the Piyungan landfill, the surrounding community, and the local government in overcoming problems related to the leachate produced from the Piyungan landfill. 


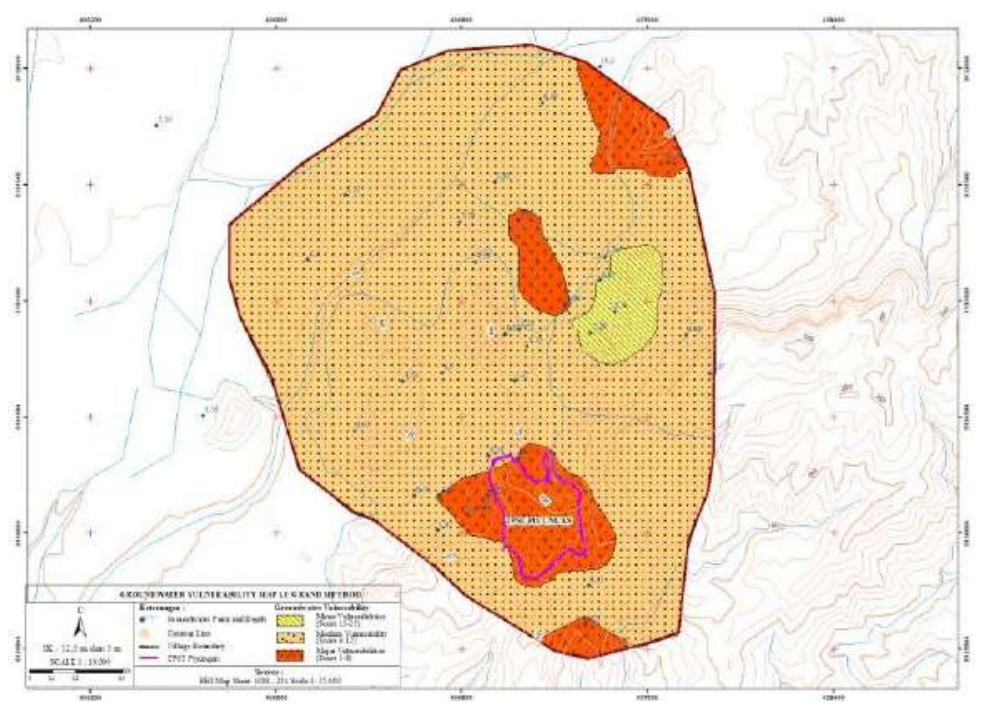

Figure 11. Map of Groundwater Vulnerability

\section{CONCLUSION AND FURTHER RESEARCH}

Based on the results of the analysis that has been carried out, it can be concluded that:

The level of vulnerability of groundwater to pollution in the area around the Piyungan landfill, Bantul Regency, D.I. Yogyakarta is divided into 3 classes of potential pollution, namely the Large Pollution Potential class (Total Score 5-8), meaning that the area can or may experience pollution; Moderate Pollution Potential Class (Total Score 9-12) which means that it has the potential to be polluted even though it is slightly; Small Pollution Potential Class (Total Score 13-25) which means it is very difficult to pollute. Because of the condition of groundwater vulnerability to pollution in the study area is dominated by medium to high vulnerability classes, so further research is needed to examine how to properly manage the landfill so as not to produce abundant leachate.

\section{REFERENCE}

ACSAD \& BGR, 2003. Guidline for Groundwater Vulnerability Mapping and Risk Assessment for the Susceptibility of Ground water Resources to Contamination. Management, Protection ans Sustainable Use of Groundwater and Soil Resources to Contamination. Project No : 1996.2189.7. Damascus.

Bhalla, B., Saini, M. S. \& Jha, M. K. 2012. Characterization Of Leachate From Municipal Solid Waste (MSW) Landfilling Sites Of Ludhiana, India : A Comparative Study. International Journal Of Engineering Research And Application. Vol 2(6) : Page 732-745.

Chunying, T., Kanggen, Z., Changhong, P. \& Wei, C. 2021. Characterization and treatment of landfill leachate: A review. Water Research. Volume 203.

Damanhuri, E. \& Padmi, T. 2016. Pengelolaan Sampah Terpadu. Penerbit ITB. Bandung.

El Baba, M., Kayastha, P., Huysmans, M. \& De Smeth, F. 2020. Evaluation of the Groundwater Quality Using the Water Quality Index and Geostatistical Analysis in the Dier al-Balah Governorate, Gaza Strip, Palestine. Water 2020. Volume 12.

Fardiaz, S. 1992. Polusi Air dan Udara. Gadjah Mada Press. Yogyakarta.

Feuyit, G., Lambi, J. N., Njoyim-Tamungang, E \& Laminsi, S. 2019. Assessment of the Nutriens in the Leachate and the Groundwater Quality for Drinking and Farming around the Nkolfoulou Landfill in Yaounde, Cameroon. Journal of Chemistry. Volume 2019. 
Gajski, G., Oreščanin, V \& Garaj-Vrhovac, V. 2012. Chemical Composition and Genotoxicity Assessment Of Sanitary Landfill Leachate From Rovinj, Croatia. Ecotoxicology And Environmental Safety. Volume 78 : Page 253-259.

Gamar, A., Zair, T., El Kabriti, M. \& El Hilali, F. 2018. Study Of The Impact Of The Wild Dump Leachates Of The Region Of El Hajeb (Morocco) On The Physicochemical Quality Of The Adjacent Water Table. Karbala International Journal of Modern Science Volume 4 (2018): Page 382-392.

Guanyi, C., Guanyun, W., Ning, L., Xukai, L., Jianhui, Z., Mengting, H., Beibei, Y., Hongqiong, Z., Xiaoguang, D. \& Shaobin, W. 2021. Landfill leachate treatment by perslphate related advanced oxidation technologies. Journal of hazardous materials. volume 418.

Ibe, K. M., Nwankwor, G. I., Onyekuru \& S. 0. 2001. Assessment of Ground Water Vulnerability and its Application to the Development of Protection Strategy for the Water Supply Aquifer in Owerri, Southeastern Nigeria. Environmental Monitoring and Assessment. Volume 67 : 323-360.

Kasam. 2011. Analisis Resiko Lingkungan pada Tempat Pembuangan Akhir (TPA) Sampah (Studi Kasus: TPA Piyungan Bantul). Jurnal Sains dan Teknologi Lingkungan. Volume 3(1) : Halaman 019-030

Kurakalva, R.M., Atadhib, K.K., Mallela, K.Y. \& Venkatayogi, S. 2016. Assessment of Groundwater Quality in and around the Jawaharnagar Municipal Solid Waste Dumping Site at Greater Hyderabad, Southern India. International Conference on Solid Waste Management. 24-27 November 2015, Bangalore, India. Volume 35 : page 328 - 336.

Machdar, I., Zulfikar, T., Rinaldi, W., \& Alfiansyah, Y. 2018. Assessment Of Groundwater Vulnerability Using DRASTIC Model And GIS : A Case Study Of Two Sub-Districts In Banda Aceh City, Indonesia. IOP Conf. Series : Material Science And Engineering. 334 (2018) 012032.

Maria, R., Anna, F.R. \& Wilda, N. 2017. Potensi Pencemaran Airtanah Di Daerah Sub-Urban Kabupaten Bandung bagian Selatan Dengan Menggunakan Metode Legrand. Proceeding Seminar Nasional Kebumian Ke-10 : Peran Ilmu Kebumian Dalam Pembangunan Infrastruktur Di Indonesia. 13 - 14 September 2017, Yogyakarta, Indonesia.

Menani, M.R. 2012. The Artificial Recharge Of The Aquifers By Considering The Groundwater Vulnerability To Pollution. Sixteenth International Water Technology Conference. 7-10 May 2012, Istanbul, Turkey.

Mepaiyeda, S., Madi., K., Gwaavava, O. \& Baiyegunhi, C. 2020. Geological And Geophysical Assessment Of Groundwater Contamination At The Roundhill Landfill Site, Berlin, Eastern Cape, South Africa. Heliyon. Volume 6 (2020).

Muryani, E. 2012. Zonasi Potensi Pencemaran Bahan Bakar Minyak terhadap Airtanah Bebas (Studi Kasus SPBU 44.552.10 Yogyakarta. Jurnal Sains dan Teknologi Lingkungan. Volume 4(2), Juni 2012, Halaman 114-124. ISSN: 2085-1227.

Naveen, B.P., Sumalathe, J. \& Malik, R. K. 2018. A Study on Contamination of Ground and Surface Water Bodies by Leachate Leakage From a Landfill in Bangalore, India. International Journal of GeoEngineering (2018).Volume 9(27).

Nnadozie, K. C., Nwankwor, G. I., Opara, A. I., Ibeh, J. C., Henry, S., Edet, E.E., \& Fagorite, V. I. 2019. Evaluation of Groundwater to Pollution Using Different Models in Njaba and Environs Southeastern Nigeria. IOSR Journal of Applied Geology and Geophysics. Volume 7 : Page 16-32.

Sari, R.N. \& Afdal. 2017. Karakteristik Air Lindi (Leachate) di Tempat Pembuangan Akhir Sampah Air Dingin Kota Padang. Jurnal Fisika Unand Vol. 6(1). Januari 2017. ISSN 2302-8491.

Singhal, B. B. S. \& Gupta, R.P. 2010. Applied Hydrogeology of Fracture Rocks : Second Edition. Springer Science \& Business Media, Berlin. ISBN 978-90-481-8798-0.

Sudibyo, H., Pradana, Y. S., Budiman, A. \& Budhijanto, W. Municipal Solid Waste Management in Indonesia

- A Study about Selection of Proper Solid Waste Reduction Method in D.I. Yogyakarta Province.

Energy Procedia. Volume 143 (2019) : Page 494-499.

Sultana, M., Waheeda, S., Alia, U., Sweetman, A.J., Jones, K.C. \& Malika, R.N. 2019. Insight Into Occurrence, Profile And Spatial Distribution Of Organochlorine Pesticides In Soils Of Solid Waste Dumping Sites Of Pakistan: Influence Of Soil Properties And Implications For Environmental Fate. Ecotoxicology and Environmental Safety. Volume 170 (2019): Page 195-204.

Thomas, R.A. \& Santoso, D.H. 2019. Potensi Pencemaran Air Lindi Terhadap Airtanah Dan Teknik Pengolahan Air Lindi Di TPA Banyuroto Kabupaten Kulon Progo. Jurnal Science Tech. Volume 5(2). Agustus 201965. 
Groundwater Vulnerability towards Pollution in Area Around the Piyungan Landfill, Bantul Regency, D. I. Yogyakarta

RR. Dina Asrifah, Ika Wahyuning Widiarti, Praditya Anggi Widhiananto, Lailiyatun Ni'ma, Dzulfiqar Izzatur Rahman, Aliendina Jwalita, Hafidz Romizah

Thyagarajan, L.P., Jeyanthi, J. \& Kavitha, D. 2021. Vulnerability analysis of the groundwater quality around Vellalore-Kurichi landfill region in Coimbatore. Environmental Chemistry and Ecotoxicology. Volume 3 (2021) : page 125-130 http://dx.doi.org/10.1016/j.enceco.2020.12.002.

Vespasiano, G., Muto, F. \& Apollaro, C. 2021. Geochemical, Geological, and Groundwater Quality Characterization of a Complex Geological Framework : The Case Study of the Coreca Area (Calabria, South Italy). Geosciences 2021. Volume 11(121). https://doi.org/10.3390/geosciences11030121.

Wanzhou, W., Mwiathi, N. F., Chengcheng, L., Wenting, L., Xin, Z., Yonghui, A., Mengnan, Z. Peili, G., Juanjuan, L., \& Xubo, G. 2022. Assessment Of Shallow Aquifer Vulnerability To Fluoride Contamination Using Modified AHP-DRASTICH Model As A Tool For Effective Groundwater Management, A Case Study In Yuncheng Basin, China. Chemosphere. Volume 286, Part 2, January 2022, 131601.

Wijaya, K.A. \& Purnama, I..L.S. 2018. Kajian Kerentanan Airtanah Terhadap Potensi Pencemaran di Kecamatan Kasihan Kabupaten Bantul. Jurnal Bumi Indonesia. Volume 7(1. 